\title{
Türkiye'de Kadına Yönelik Şiddet Konusunu İçeren Medya Yayınlarının İçerik Analizi İle İncelenmesi
}

\author{
DOI: $10.26466 /$ opus. 814844 \\ *
}

\author{
Begüm Yetișer* \\ * Y1 Öğr., 9 Eylül Üniversitesi, İşletme Yönetimi, İzmir/Türkiye \\ E-Posta: yetiserbegum@gmail.com \\ ORCID: 0000-0001-9613-1467
}

\begin{abstract}
Öz
Kadına yönelik şiddet, bir toplumsal sorundur. Kitle iletişim araçları ise, doğru kullanıldığı takdirde her türlü toplumsal sorun için bir çözüm yolu sunabilir. Özellikle çeşitli kurum veya kuruluşlar tarafindan oluşturulan kamu spotları, toplumu konu hakkında bilinçlendirmek için önemli bir araçtır. Kadına yönelik şiddeti durdurmaya yönelik kitlesel medyada atılan her adım, geniş kitleler tarafindan izlendiği için, oldukça önem taşımaktadır. Bu çalışma, kadına yönelik şiddet konulu kamu spotlarının analizinden oluşmaktadır. Makalede Türkiye'de yayımlanmış kadına yönelik şiddet temalı kamu spotu ve sosyal reklamlar içerik analizi yöntemi ile incelenmiştir. İçerik analizi sonucunda kadına yönelik şiddet temalı kamu spotlarının belli başlı sonuçları özetlenmiştir. İçerik analizinin sonuçlarına göre kamu spotlarında en çok negatif bir mesaj tonunun kullanıldığı, bu mesaj verilirken kadın, erkek ve çocuğun genellikle bir arada gösterildiği ve bu negatif duyguların hikâyeleştirilerek sunulduğu görülmüştür. Ayrıca, kamu spotu yayınlarında kadınların genellikle yardıma muhtaç ve üzgün olarak gösterildiği görülmektedir. Buna ek olarak şiddetin kaynağı olarak görülen erkeğe kuralları hatırlatan, şiddete maruz kalan kadına ise yardıma ihtiyaç duydukları anlarda nasıl yardıma ulaşacaklarım anlatan kamu spotları bulunmaktadır. Bu çalışma, kadına şiddet ve kamu spotları konusunda Türk yazınında yer alan öncü çalışmalardan birisi olması nedeniyle önemli bir çalı̧̧madır.
\end{abstract}

Anahtar Kelimeler: Kamu spotu, kadına yönelik şiddet, içerik analizi. 


\title{
Content Analysis of Public Service Announcements That Focus on Violence Against Women
}

\begin{abstract}
Violence against women is a social problem. Mass media, can offer a solution for all kinds of social problems if used correctly. Public service announcements are important tools to raise societal awareness about violence. Every step taken in the mass media to stop violence against women is very important as it is watched by large masses. This study consists of the analysis of public service ads on violence against women. In the article, violence against women-themed public service ads and social advertisements published in Turkey were analyzed by content analysis method. As a result of the content analysis, the main results of the public service ads with the theme of violence against women were summarized. According to the results of the content analysis, it was seen that a negative message tone was mostly used in public advertisements. In addition, this message was given by women, men and children that were generally shown together and these negative feelings were presented as a story. In addition, it is seen that women are often depicted as needing and sad in public service announcements. Results also showed that there are public service announcements that reminded men who are seen as the source of violence and how they can reach out to women who are subjected to violence when they need help. This study is an important study as it is one of the pioneering studies in Turkish literature on violence against women and public service ads.
\end{abstract}

Keywords: Public service announcements, violence against women, content analysis. 


\section{Giriş}

Şiddetin geçmişi, neredeyse insanlık tarihi kadar eskidir. Şiddet; fiziksel, politik, toplumsal ve terör odaklı nedenlerden kaynaklanabilecek çok yönlü bir sorunlar bütünüdür (Uslusoy, 2016, s.2134). Dolayısıyla şiddeti tek bir boyuta indirgemek kolay değildir (Türkoğlu, 2013: 146). Şiddet, Dünya Sağlık Örgütü'nün raporuna göre üç geniş tipoloji altında sınıflandırılmıştır (Krug, Mercy, Dahlberg, ve Zwi, 2002, s 6). Bu sınıflandırma (1) kişinin kendisine yönelik şiddet, (2) kişiler arası şiddet ve (3) toplumsal şiddet şeklindedir. Kişinin kendisine yönelik şiddet kişinin kendisine zarar verdiği şiddet türüdür. Bu; bedeni fiziksel olarak incitmek, kendini aşağılayan kelimeleri kullanmak vb. davranışlardan oluşan bir şiddet türüdür. Kişiler arası şiddet ise kasıtlı olarak bir diğerine fiziksel, psikolojik ve ekonomik olarak zarar verildiği durumlarda ortaya çıkan şiddet türüdür. Son olarak, insanların toplu olarak şiddet uygulamasına toplu şiddet denir. Toplu şiddet, büyük çaplı ayaklanmalara sebebiyet verebilmektedir. Bir mağazaya saldıran bir grup insan toplu şiddete örnektir. Şiddet, sadece kadınlara değil, aynı zamanda erkeklere, çocuklara, bebeklere, yaşlılara, hayvanlara ve doğaya karşı işlenen küresel bir suçtur. Bununla birlikte, insandan insana şiddet söz konusu ise, fiziksel kuvvet eksikliği nedeniyle, kadınlar, çocuklar, bebekler ve yaşlılar istismar mağduru olmaktadırlar (Akkuş ve Yıldırım, 2018, s.1369). Ülkemizde özellikle son on yılda şiddet vakaları hızla artış göstermiş, herhangi bir sebepten ortaya çıkabilen, gitgide büyüyen toplumsal bir sorun haline gelmiştir. Bu bağlamda kitle iletişim araçları kadına yönelik şiddet ile mücadele kapsamında önemli bir rol üstlenmektedir. Bu araçlar, yeni rol modelleri oluşturarak bireylerin davranışlarını, inançlarını, tutumlarını ve dünya görüşlerini etkileyebilir (Türkoğlu, 2013, s.147). Daha da önemlisi, ana akım medya ve sosyal medya, sosyal olayların başlatılmasinda ve planlanmasında yardımcı olabilir (Öztürk, 2015, s.261). Bu nedenle medyanın şiddet hakkında toplumla nasıl iletişim kurduğu çok önemlidir. Bu bağlamda kamu spotları ve sosyal reklamlar, kadına yönelik şiddetin azaltılmasına yönelik oluşturulmuş önemli yayımlardır. Kamu spotları 1 dakikadan kısa sürelidir, basit dille ifade edilmiştir ve akılda kalıcı bir şekilde oluşturulmuştur (Umunç, 2019, s.1317). 
Bu çalışmada amaç, kadına yönelik şiddet temalı kamu spotlarının 14 adet araştırma sorusu kapsamında incelenmesidir. Bu doğrultuda kamu spotu yayınları içerik analizi yöntemi ile incelemiştir. Çalışma, beş bölümden oluşmaktadır. İlk bölümde kadına yönelik şiddet konusu ele alınmıştır. İkinci bölüm literatürde yer alan kadına şiddet ile ilgili medya çalışmalarından oluşmaktadır. Üçüncü ve dördüncü bölümler çalışmanın metodunu ve çalışma bulgularını irdelemekte, son bölüm ise sonuç ve tartışmadan oluşmaktadır.

\section{Dünya'da ve Türkiye'de Kadına Yönelik Şiddet}

Dünyanın dört bir yanındaki yetişkin kadınlar; yaşlarına, etnik kökenlerine, dinlerine, ekonomik veya sosyal durumlarına bakılmaksızın şiddet tehdidiyle karşı karşıyadır (Karaca, Barlas, Öngün, Öz, ve Korkmaz, 2017, s.139). 2019 yılında oluşturulan WHO raporuna göre Dünya genelinde kadınların 3'te 1'i (35\%) fiziksel ve/veya cinsel saldırıya maruz kalmaktadır.

Kadına yönelik şiddet; fiziksel, cinsel, psikolojik ve ekonomik şiddet olmak üzere dört gruba ayrılmaktadır. Fiziksel şiddet, bireyin fiziksel olarak başka bir bireye zarar vermesini içeren şiddet türüdür. Şiddet gösteren birey, mağdurun yakın çevresinde olan samimi bir kişi (ortak, akraba, arkadaş) veya bir yabancı olabilir. En sık rastlanan fiziksel şiddet örnekleri: tokat atmak, vurmak, tekmelemek ve dövmektir (GarcíaMoreno, Jansen, Ellsberg, Heise, ve Watts, 2005, s.14). Bunun dışında, fiziksel şiddet örnekleri; “... size zarar verebilecek eylemlerden tokatlanmak veya atılmak, itilmek, yumrukla vurulmak veya incitmek, tekmelenmek, sürüklenmek veya dövülmek, boğulmak veya kasıtlı olarak yakılmak ve/veya silah, bıçak veya başka bir silahı kullanmakla tehdit edilmek" şeklindedir (García-Moreno, vd., 2013, s.6). Türkiye'de Aile ve Sosyal Politika Bakanlığı tarafından yürütülen kadına yönelik aile içi şiddet konusunda yapılan geniş bir araştırma, kadınların \%36'sının yakın partnerinden fiziksel şiddet yaşadığını, ayrıca boşanmış/ayrı yaşayan kadınların \%73'ünün eski partnerleri tarafından fiziksel istismara uğradıklarını belirtmiştir (Hacettepe Üniversitesi Nüfus Etütleri Enstitüsü [HÜNEE], 2015, s.52). 
Şiddetin bir başka türü de cinsel şiddettir. Cinsel şiddet, bir bireyin rızası olmadan başka bir kişiyi isteyerek istismar ettiği başka bir şiddet türüdür. Eşler arası cinsel şiddet şu şekilde tanımlanır: “... İstemediğiniz zaman cinsel ilişkiye girmek için fiziksel olarak zorlanmak, eşinizin yapabileceklerinden korktuğunuz için cinsel ilişkiye girmek ve/veya zorlanmak, aşağılayıcı veya aşağılayıcı bulduğunuz cinsel bir şey yapmak zorunda kalma" şeklindedir (García-Moreno, vd., 2013, s.6). Eşi olmayan kadınların uğradığı cinsel şiddet ise: “... Kocanız/partneriniz dışında bir kişi tarafından istemediğiniz herhangi bir cinsel eylemde bulunmaya zorlanma" şeklinde tanımlanır (García-Moreno, vd., 2013, s.6). Türkiye'de ise kadınların en çok boşanmış oldukları eşleri tarafından (\% 44) ve mevcut eşleri tarafından (\%14) cinsel istismara uğradıklarını göstermiştir (Hacettepe Üniversitesi Nüfus Etütleri Enstitüsü [HÜNEE], 2015, s.52).

"Hasıraltı" edilebilecek ve farkında olunması diğer şiddet türlerine göre daha güç olan bir diğer şiddet türü ise psikolojik şiddettir. Psikolojik şiddet, bir bireyin başka bir bireye karşı aşağılayıcı bir dil kullanması sonucu meydana gelir. Psikolojik şiddet; “...kadını kamusal ya da özel alanda aşağılamak, evden çıkmasını yasaklamak ya da onu kilitlemek, pornografik materyalleri isteklerine karşı izlemek, korkutmak, şiddetle tehdit etmek ya da başka birine zarar vermekle tehdit etmek (şantaj), çocukları kadından uzaklaştırmakla tehdit etmek, çocuklara zarar verme ya da onlara zarar verme tehdidinde bulunmak..." (Nevala, 2014, s.7173) şeklindedir. Türkiye'de evli kadınların \%44'ünün psikolojik olarak çeşitli şekillerde suiistimal edildiği Hacettepe Üniversitesi Nüfus Etütleri Enstitüsü'nün düzenlediği Türkiye araştırması tarafından (2015: s.52) belirlenmiştir. Busuiistimalin en önemli gerçekleşme şeklinin ise \%37 oranında hakaret ve küfür olduğu ortaya konmuştur (Hacettepe Üniversitesi Nüfus Etütleri Enstitüsü [HÜNEE], 2015, s.52).

Fiziksel ve cinsel istismar türleri kadınlara yönelik en yaygın istismar türü olmasına rağmen, kadınları kontrol etmek söz konusu olduğunda, finansal özgürlüklerini ortadan kaldırmak da tehlikeli bir istismar yoludur. Ekonomik şiddet, bir bireyin başka bir bireyin ekonomik durumunu isteyerek sinırladığı, azalttığı veya kontrol ettiği bir şiddet türüdür. Bu tür şiddet içeren davranışlar, kadınlara hayatta kalabilmek için yeterli parayı vermemeyi, kadınların çalışmasına izin vermemeyi ve çalışıyorlarsa, paralarını almayı içermektedir. 2017 yılında yapılan bir araştırma, 
kadının gelir seviyesi arttıkça, şiddet görme olasılığının azaldığını tespit etmiştir (Ediz ve Altan, 2017, s.403). Türkiye'de Çalışkan ve Çevik (2018, s.225), kadına yönelik şiddetle ilgili 2008 yılında yapılmış bir araştırmanın verilerini yeniden incelemiştir. Bu çalışma, -toplumdaki genel kanının aksine- kendi mali kaynakları olan kadınların ekonomik olarak eşlerine bağımlı olan kadınlardan \%32 oranında daha fazla şiddet yaşadıklarını ifade etmiştir (Çalışkan ve Çevik, 2018, s.232). Diğer bir çalışmada ise, aile içi şiddetin kadınların çalışma yaşamları üzerindeki etkisi incelenmiş ve istismara uğramış kadınların işlerini, ev ortamından uzaklaşmak için kullandıkları görülmüştür. Örneğin evden kaçmak için işe gitmek ya da fazla mesai yapmak istemek bu davranışlara iki örnektir (Wettersten, Rudolph, Faul, Gallagher, Trangsrud, Adams, Graham ve Terrance, 2004, s.453-454).

Şiddetin türlerinin yanı sıra, sonuçlarının da bilinmesi son derece önemlidir. Şiddetin genel olarak fiziksel ve psikolojik (utanç, suçluluk, öfke, yalnızlık, başarısızlık ve yetersizlik, vb. duyguları) sonuçları vardır. Şiddetin fiziksel sonuçları; bireyde yaralanma, sakatlık, vücut parçalarının kırılması veya yerinden çıkması, organ kaybı vb. gibi kısa veya uzun vadeli etkilere neden olabilmektedir (Altıparmak, 2015, s.452). Yakın tarihli bir WHO raporu (2013, s.26), eşlerinden fiziksel istismar gören kadınların cinayete kurban gitme olasılıklarının \%38'e kadar yükseldiğini belirtmiştir.

\section{Kadına Yönelik Şiddet ile Mücadele ve Kamu Spotlarının Rolü}

Her geçen gün daha sık duyulmaya başlanan kadına yönelik şiddet konusunda, hızlı bir şekilde etkili önlemlerin alınması gerektiği açıktır (Altıparmak, 2015, s.450). Bu doğrultuda, Türkiye'deki önemli kuruluşlar da istismar edilmiş kadınlarla doğrudan veya dolaylı olarak çalışmaktadır. İlk örnek, 1990 yılında kurulmuş olan Mor Çatı Vakfı'dır. Mor Çatı vakfı, fiziksel şiddete maruz kalan kadınların meslek bulmalarına, konaklama sağlamalarına yardımcı olmaktadır. Kadav ise Kadın Dayanışma Vakfı ismi ile kadınların her türlü legal ve/veya psikolojik sorunlarına yardımC1 olarak faaliyete girmiştir. 2007 yılında bir başka destek merkezi olan ve şiddete maruz kalan kadınlara ücretsiz danışmanlık hizmeti veren KAHDEM kurulmuştur (Kadınlara Hukuki Destek Merkezi). Ayrıca, 
2012 yılında şiddeti önlemek için Türkiye'de Aile ve Sosyal Politikalar Bakanlığı tarafından önemli bir yasa oluşturulmuştur. Bu kanun (6284 sayılı kanun), Türkiye'nin her şehrinde Şiddet Önleme ve İzleme Merkezlerinin (ŞÖNIM) kurulmasına izin vermiştir (Altıparmak, 2015, s.449). ŞÖNIM merkezlerinin önemli amaçlarından biri, eskiden her bir üniteden (psikoloji, sağlık kontrolü, polis raporu, ...) ayrı ayrı geçmesi gereken kadınların travmalarını ortadan kaldırmak için çeşitli birimleri (sağlık bakımı, güvenlik önlemleri almak, psikolojik destek almak gibi) tek bir çatı altında toplayarak destekleyici bir kurum oluşturmaktır. Böylece kadınlar aynı travmatik deneyimi tekrar anlatmak zorunda kalmadan tek bir merkezde mağduriyetlerini anlatabilecek, paylaşabilecek ve çözüm yolları bulabileceklerdir. ŞÖNIM'in amacı, kadına yönelik şiddeti önlemek için koordinasyonu sağlamak ve şikâyetler toplamak için destekleyici eylemlerde bulunmaktır (Tozlu ve Göksel, 2016, s.44). Son zamanlarda çarpıcı kamu spot yayınları ile farkındalık oluşturan Kadın ve Demokrasi Derneği ise (KADEM) 2013 yılında şiddeti önlemek amacıyla faaliyetlerine başlamıştır. 2015 yılında şiddet mağduru kadınlara ve çocuklara yardımcı olmayı amaçlayan IMDAT vakfı kurulmuştur. Kadına yönelik şiddet kapsamında yapılan uluslararası antlaşmalar da en az kurulan birlik, dernek ve vakıflar kadar önem taşımaktadır. Bu antlaşmalar, uygun yasaları belirlemektedir. Cinsiyet ayrımcılı̆̆ının ve şiddetin son bulması amacıyla uluslararası CEDAW sözleşmesi 1979 yılında Birleşmiş Milletler Genel Kurulu'nda dile getirilmiştir. 30 maddeden oluşan bu antlaşma, kadınlara karşı yürütülen her türlü ayrımcılığın son bulması amaciyla ortaya konmuş kurallar bütünü olmaktadır. 2011 y1lında ise, Avrupa Konseyi Bakanlar Komitesi, İstanbul'da bir başka antlaşmayı daha imzalamıştır. Antlaşma, kadına yönelik ve aile içi şiddetin önlenmesi ve şiddet ile mücadele edilmesi amacını gütmektedir. Bu antlaşma İstanbul sözleşmesi olarak geçmektedir. Daha sonra, TBMM'de 6284 sayılı ailenin korunması ve kadına yönelik şiddetin durdurulmasını amaçlayan kanun yürürlüğe girmiştir.

Tüm bu kuruluşların sağladıkları katkıların yanı sıra, kadına yönelik şiddete karşı farkındalığı artırmak ve kuruluşların varlıkları da dâhil olmak üzere pek çok bilgiyi halka sunmak adına kitlesel iletişimi yerinde kullanmak çok önemlidir. Bir çalışmada, “...teknoloji hikâyelerimizi anlatmamıza, başkalarının haberlerini duymamıza ve kitlesel mesajlaş- 
mayı olumlu sosyal normlara yaymamıza yardımcı oluyor, ama aynı zamanda susturmak için de kullanılıyor olabilir" denmiştir (Haylock, Cornelius, Malunga, ve Mbandazayo, 2016, s.241). Dolayısiyla kitlesel iletişimin bir kolu olan medyanın doğru bir şekilde kullanılması önem taşımaktadır.

Aile ve Sosyal Politikalar Bakanlığı, sivil toplum örgütleri, belediyeler ve çeşitli medya kuruluşları kitapçık, broşür, afiş, gibi pek çok bilgilendirici doküman hazırlamaktadır. Kadına şiddet temalı görsel yayınlar ise; sosyal reklam, belgesel, röportaj, haber yayını, kamu spotu, özgün filmler, kısa filmler, şeklinde örneklenebilir. Bu çalışmada yalnızca kadına yönelik şiddeti durdurmayı amaçlayan görsel arşivlere ve bu bağlamda yayımlanmış kamu spotu ve sosyal reklama yer verilmiştir. Kamu spotları, toplumda uyulması gereken davranışlar hakkında toplumu bilgilendiren ve sağlık, emniyet, güvenlik gibi konularda uyulması gereken davranışlar hakkında uyarı ve önerilerde bulunan teşvik edici kısa reklamlardır (Bütün, Selçuk, Akandal, ve Gülseçen, 2018, s.274). Günümüzde kamu spotları, internet ve sosyal medyada paylaşılarak Umunç, 2019, s. 1317), daha çok izleyiciye ulaşmaktadır. Bu durum toplumsal farkındalığın ilerlemesi açısından olumlu bir gelişmedir.

Türkiye'de yayımlanan kamu spotları ile ilgili çeşitli çalışmalar mevcuttur. Bu çalışmalardan bazıları şunlardır: Bilis (2014) Türkiye'de 2014 yılına kadar yayımlanmış 161 adet kamu spotunu incelemiştir. Zalluhoğlu, Karslı, Candemir, ve Günay, (2015) Türkiye'de 2012-2016 yılları arasında yayımlanmış 168 adet kamu spotunu ve 84 adet zorunlu yayını incelemiştir. Özbük ve Öz (2017) ise 2012-2016 yılları arasında Türkiye'de gösterilmiş 375 adet kamu spotunu içerik analizi ile incelemiştir. Şeker ve Tiryaki (2013) ve Yaman ve Göçkan (2015) ise yalnızca sigarayı bırakma ile ilgili spotları ele almıştır. Diğer çalışmalar ise, 2017 ve 2018 yılarında yayımlanmış bazı kamu spotlarını gösterge-bilimsel olarak incelemiştir (Göçmen ve Ayvaz, 2017; Gülada, 2018; Tanca ve Ünal, 2018). Kadına şiddet konusu çerçevesinde hazırlanmış kamu spotlarının incelenmesi kapsamında da çalışmalar mevcuttur. Ergeç ve Zateri (2015) yaptıkları çalışmada, 12 kişiden oluşan iki farklı homojen odak gruba "8 Mart 8 Kadın" isimli kamu spotunu izleterek spot hakkındaki yorumlarını analiz etmiştir. Kadın ve erkeklerle yapılan odak grup çalışmasının sonucunda şiddetin insanlık suçu olduğunun vurgulanması gerekliliği 
ortaya çıkmıştır. Vodinalı ve Akıncı (2019, s.48) “Biz Varız" isimli kamu spotunu söylem analizi yöntemi ile incelemiştir. Bu kamu spotunda şiddet olayı gerçekleştikten sonra çaresizlik içerisinde kalmış kadına güven aşılandığı, kendisini güvende hissedebileceği, sığınabileceği devlet eli uzatılmaktadır. Umunç (2019) kadına yönelik şiddet temalı üç adet kamu spotunu gösterge bilimsel olarak incelemiştir. Sonuçlara bakıldığında, incelenen kamu spotlarının erkek egemen yapıyı pekiştirdiği, çözümün yalnızca erkekte arandığı bulunmuştur. Umunç (2019) böylece çalışmasında cinsiyet eşitsizliğinin bir kamu spotu yayını içerisinde dahi devam ettirildiğini ifade etmiştir. Literatürde, bir veya birden fazla kamu spotunun seçilerek bu spotların gösterge bilimsel olarak incelendiği görülmüştür. Ancak kadına yönelik şiddet temalı çalışmaları bir araya getirip içerik analizi ile inceleyen bir çalı̧̧ma bulunmamaktadır. Kadına yönelik şiddet temalı kamu spotlarının incelenmesi ve içerik analizi ile bir araya getirilmesi oldukça önemlidir. STK'lar, bakanlık ve belediyeler, ancak belirli semtlerde, belirli saatlerde, belirli kitlelere eğitimler düzenleyerek ve çok yoğun çalışarak şiddetsizliğin yayılması için üstün çaba sarf etmektedir. Ancak kitlesel medya, her eve girmiş olup, her saat ve dakika toplumun her kesimi tarafından izlenmektedir. Dolayısıyla kamu spotlarında verilen mesajların ne olduklarının bir bütün halinde incelenmesi kadına şiddet temasının hangi düzeyde ve nasıl kullanıldığının öğrenilmesi açısından yerinde olacaktır. Dolayısıyla bu çalışma, literatürdeki bu boşluğu doldurarak literatüre katkı sağlayacak ve konuyla ilgili çalışan araştırmacılara ışık tutacaktır.

\section{Yöntem}

Bu çalışma 2020 Ocak ayı içerisinde gerçekleştirilmiştir. Araştırmaya, 2000 ile 2019 yılları arasında yayınlanan kadına yönelik şiddet temalı 65 adet yayın dahil edilmiştir. Bu yayınların tümü kadına yönelik şiddet temasına sahiptir. Yayınlar, Aile ve Sosyal Politikalar Bakanlığı'nın Youtube platformu üzerindeki e-arşivinden, Aile İçi Şiddete Son kampanyası Youtube kanalından ve çeşitli internet video kaynaklarından bulunmuştur. Analiz yöntemi olarak nitel içerik analizi kullanılmıştır.

Pek çok çalışmada kullanılan (Chang, Jackson ve Grover, 2003) içerik analizi, nitel araştırma yöntemleri arasında en sık kullanılan yöntemler- 
den biridir (Hsieh ve Shannon, 2005). İçerik analizi yöntemi, belirli bir sayıda materyalin, önceden belirlenmiş (Nakip ve Yaraş, 2016, s.126) veya araştırmanın amacına göre yeniden düşünülerek oluşturulmuş araştırma kriterlerine göre (Hsieh ve Shannon, 2005, s.1281) irdelenmesidir. İçerik analizinin kodlama şemasını tasarlarken araştırmacılar, uzunca listelenmiş hazır kodları mi, yoksa araştırma sorularına uygun olan kodları mı kullanmalılar, düşünmelidirler. Bu nedenle her nitel analizin farklı birtakım özellikleri taşıdığı ve her araştırmanın veri analizinde farklı yaklaşımlar ile açıklanması gerektiği düşünülmektedir. Bu çalışmada, içerik analizine göre görsel materyaller incelenmiş, bu materyallerdeki belli başlı kriterler sistematik olarak sınıflandırılmış ve frekans dağılımı yöntemi ile sayılara dönüştürülmüştür. Belirlenen kriterler, araştırmanın amacına uygun bir şekilde kodlanarak analiz edilmiş ve yorumlanmıştır (Stemler, 2001, s.137).

Tablo 1. Araştırmada Kullanılan Kodlar

\begin{tabular}{lll}
\hline Kampanyanın Türü & Yayımlayan Kurum & Kadın Kullanımı \\
\hline Kamu spotu & Medya Kuruluşu & Var \\
Sosyal Reklam & Bakanlık & Yok \\
Mesajın Tonu & Kolluk Kuvvetleri & Teknoloji Önerisi Sunma \\
Pozitif & Birlik/Dernek/Vakıf & Varlığı \\
Nötr & Belediye/Valilik & Var \\
Negatif & Mesajın Amacı & Yok \\
Mesajın Veriliş Şekli & Bilgi Verme & Kişi Kullanımı \\
Hayattan Kesit & İkna Etme & Kadın \\
Yaşam Tarzı & Hatırlatma & Erkek \\
Fantezi & Müzik Varlığı & Çocuk \\
Yalnızca Duygu veya Görün- & Var & Karma \\
tü Kullanımı & Yok & Hayvan \\
Müzikal & Renk Varlığı & Hiçbiri \\
Kişilik Sembolü & Renkli & Mesajın Kaynağının... \\
Teknik Uzmanlık & Siyah-Beyaz & Uzmanlığı \\
Bilimsel Kanıt & Mesajın Kimin Tarafından Verildiği & Güvenilirlik \\
Sözel Kanıt & $\ddot{n}$ Ün̈̈ & Beğenilirlik \\
Duygu Kullanımı & Dış ses & Önlem İnisiyatifi \\
Utanma & Uzman & Birincil \\
Sevgi & Hayattan Birisi & İkincil \\
Öfke & Hiçbiri & Üçüncül \\
Hüzün & & \\
Korku & & \\
Nese/Coşkunluk & & \\
Hiçbiri & & \\
\hline & & \\
\hline & & \\
\hline
\end{tabular}


Bu tabloda kullanılan referanslar: Mesajın Amacı (Kotler, vd., 1999, s. 795); Mesajın Tonu (Kotler, vd., 1999, s. 802); Mesajın Veriliş Şekli (Kotler, vd., 1999, s. 801); Müzik Varlığı (Özbük ve Öz, 2017, s. 580-581); Mesajin Kaynağı (Kotler, Shalowitz, ve Stevens, 2008, s. 390).

Tablo 1'de görülmekte olan ayrıntılı bilgiler kodlamaya dahil edilen araştırma sorularını ve alt kriterlerini özetlemektedir. Öncelikle kadına yönelik şiddet temalı yayınların türünü anlamak gerekir. Bu çalışma yalnızca kamu spotu ve sosyal reklam yayınlarını hedef almıştır. Bu sebeple çalışmanın ilk araştırma sorusu şu şekilde belirlenmiştir:

Araştırma sorusu 1: Kadına yönelik şiddet temalı yayınlar kamu spotu ve sosyal reklam olarak nasıl dağılım göstermektedir?

Araştırma sorusu 2: Kadına yönelik şiddet temalı yayınları hangi kuruluşlar yayınlamaktadır?

Araştırma sorusu 3: Kadına yönelik şiddet konulu yayınların süresi nedir?

Şiddeti durdurmak için birincil, ikincil ve üçüncül olmak üzere üç düzey önlem inisiyatifi bulunmaktadır (Krug vd., 2002, s.15): Birincil önlemler (sorun oluşmadan önce hareket etmek), ikincil önlemler (ilk şiddet belirtileri görüldüğünde sorunu azaltmak için hareket etmek) ve üçüncül önlemler (sorun oluştuğunda hareket etmek). Birincil önlemler, şiddetin gerçekleşmeden önce engellenmesini içerir. İkincil önlemler potansiyel şiddetin oluşmasını azaltabilecek stratejileri kapsar. Üçüncül müdahalelerde ise şiddet meydana geldikten sonra stratejiler geliştirilir. Sosyal pazarlama kampanyaları; şiddeti, şiddet eylemi gerçekleşmeden önce, gerçekleştiği sırada ve gerçekleştikten sonra durdurmayı amaçlayan birincil, ikincil ve üçüncül önleme müdahalelerinin her birinin bir parçasıdır. Araştırmaya dahil edilen kamu spotu ve sosyal reklamların birincil, ikincil ya da üçüncül önlem kapsamında olup olmadığı çalışmanın dördüncü sorusu olmaktadır;

Araştırma sorusu 4: Kadına yönelik şiddet konulu kamu spotu ve sosyal reklamlar hangi tip önlem inisiyatifini vurgulamaktadır?

Reklamlarda verilen mesajın tonu, literatürde, pozitif, negatif, ve nötr olarak belirlenmiştir (Kotler, vd., 1999, s.802). Kadına yönelik şiddetin negatif sonuçlarını irdeleyici (negatif ton), kadına yönelik şiddetle mücadele sonunda oluşabilen bir başarı hikâyesini veya şiddetsizlik örneğinin olumlu örneklerini (pozitif ton) işaret edebilir. Bazı yayınlar ise yalnızca bilgilendirme içereceğinden, yayın içerisinde nötr bir ton kullana- 
bilir. Yayınlarda kullanılmış tonu bilmek amacıyla bir diğer araştırma sorusu irdelenecektir;

Araştırma sorusu 5: Kadına yönelik şiddet temalı yayınlardaki mesaj tonu ne sıklıkla görülmüştür?

Kamu spotları hem inandırıcı, hem de duygusal tepki uyandırıcı olma özellikleri ile izleyici ile etkin iletişimi sağlamaktadır (Dillard ve Peck, 2000, s.461). Yayınlarda ortaya çıkacak duyguları belli başlı duygular ile eşleştirebilmek adına, literatürde en sık kullanılan duygu kategorilerinden birine (Shaver, Schwartz, Kirson, ve O'Connor, 1987) başvurulmuştur. Buna göre yayınlarda açı̆̆a çıkan en baskın duygu; sevgi, neşe/coşkunluk, öfke, hüzün ve korku şeklindedir. Ancak bu duygu kategorilerine utanma duygusu da eklenmiştir. Edelmann (1985, s.195) utanma duygusunu "... sosyal etkileşim üzerinde yıkıcı bir etkiye sahip olabilecek yaygın ve rahatsız edici bir sosyal kaygı biçimi" olarak tanımlar. Utanma duygusu, kadına yönelik şiddet kapsamındaki durumlarda özellikle kadınlar tarafından hissedilen bir duygu olmaktadır. Kadınlar kamu spotunu izleseler dahi utanıp başvurmaları gereken merkezlere başvuramamaktadır. Şiddet içeren deneyimlerini paylaşmamanın yaygın nedenleri literatürde (1) korkmak (aileye utanç getirmek; kendini suçlamak, şikayet nedeniyle daha da tehdit edilmek), (2) utanç ve (3) şiddetin normalleştirilmesi olarak özetlenmiştir (García- Moreno vd., 2005, s.77). Bir başka açıdan, erkeklerin şiddet uyguladıkları için herhangi bir utanma duygusu geliştirmedikleri toplumda gözlemlenebilir. Ergeç ve Zateri $(2015$, s.77) odak grup çalışması gerçekleştirmişler ve erkek katılımcıların şiddet ile erkeğin bağdaşmasından utanç duyduklarını belirtmişlerdir. Buna göre hem kadınlar hem de erkekler için utanma duygusu farklı eylemlere sebebiyet verecek olsa dahi, şiddeti önleyecek adımların atılmasına yardımcı olacaktır. Kamu spotu ve sosyal reklam gibi yayınlarla utanma duygusunun kullanılması bu açıdan önemlidir. Buna göre araştırma sorusu aşağıdaki gibidir;

Araştırma sorusu 6: Kadına yönelik şiddet temalı yayınlarda hangi duygu en sık şekilde açı̆̆a çıkmıştır?

Kamu spotunun uyandırdığ 1 duygu ve tonlama, kamu spotu ve sosyal reklamlarda verilen mesajın hangi öğelerden beslendiğine bağlıdır. Borzekowski ve Poussaint (2000, s.174) kamu spotlarının etkinliği hakkında yaptıkları çalışmada (1) farklı kişiliklerin, (2) görsel öğelerin ve (3) 
direkt verilen mesajın yayının kendisinden daha etkili olduğunu bulmuşlardır. Bu bağlamda yayınlarda kullanılan kişiler (erkek, kadın, çocuk, hayvan, karma, hiçbiri), bu kişiler arasında kadının varlığı kriterlere eklenmiş, görsel öğe olarak ise müzik (Özbük ve Öz, 2017, s.580-581) ve renk kullanımı kriterlere eklenmiştir. Şu halde;

Araştırma sorusu 7: Kadına yönelik şiddet temalı yayınlardaki kişiler ne sıklıkla görülmüştür?

Araştırma sorusu 8: Kadına yönelik şiddet temalı yayınlarda kadın karakterlerin yer alma sıklığı nedir?

Araştırma sorusu 9: Kadına yönelik şiddet temalı yayınlarda müzik kullanılmış mıdır?

Araştırma sorusu 10: Kadına yönelik şiddet temalı yayınlarda renk kullanılmış mıdır?

Mesajın ikna ediciliğinin artması için mesajı veren kaynağın da etkin bir figür olması önemlidir (Petty ve Cacioppo, 1984). Buna göre mesajın kimin tarafından verildiği önemlidir. Mesajı veren kişiye ait kriterler; ünlü, uzman, hayattan bir kişi veya diş ses olarak belirlenmiştir. Buna göre bir diğer araştırma sorusu şu şekildedir;

Araştırma sorusu 11: Kadına yönelik şiddet temalı yayınlarda mesaj kim tarafından verilmiştir?

Mesajı veren kaynağın izleyicide etki bırakması önem taşımaktadır (Kareklas, Muehling, ve Weber, 2015, s.99; Kotler, Shalowitz ve Stevens, 2008, s.390). Oluşturulan kriterler, Kotler, Shalowitz ve Stevens'ın (2008, s.390) çalışmasından edinilmiştir. Bu kriterler, kaynağın beğenilirliği, uzmanlığ ve güvenilirliğidir. Beğenilir kişiler (ünlü kişi, politikacı) mesajın beğenilirliğini kişiliklerine karşı duyulan sempati dolayısıyla yaratmaktadır. Uzman kişiler (psikolog, doktor) bilimsel kanıt sunarak verilen mesaja duyulan güveni artırmaktadır. Güvenilir kişiler ise (STK üyesi/başkanı, meclis üyesi, dernek/birlik üyesi/başkanı, belediye kurum çalışanları) sözel kanı sunarak genelde otoriter bireyler oldukları için mesajın ciddiyetini ortaya koymakta ve yine güven sağlamaktadır. Dolayisiyla;

Araştırma sorusu 12: Kadına yönelik şiddet temalı yayınlarda mesaj1 veren kaynağın güvenilirlik, beğenilirlik, uzmanlık ölçütleri ne sıklıkla kullanılmıştır? 
Literatürde mesajın veriliş şekli de yayındaki hikayeyi doğru aktarabilmek açısından önem taşımaktadır. Bu kriterler literatüre uygun olarak hayattan kesit, yaşam tarzı, fantezi, yalnızca duygu ya da görüntü kullanımı, müzikal, kişilik sembolü, teknik uzmanlık, bilimsel kanıt ve sözel kanıt şeklinde listelenmiştir (Kotler, vd., 1999, s.801). Literatürde listelenen unsurlardan uygun olanlar açıklanmıştır. Örneğin, hayattan kesit, hayatın içinden bir sahnenin sunulması, örneğin şiddet vakasının yaşandığı bir ev yaşantısı sahnesi ile gerçekleşir. Yaşam tarzı, şiddetin benimsendiği (veya benimsenmediği) durumlardaki yaşantıyı gözler önüne serebilir. Eğer yayın yalnızca görüntü kullanmışsa, animasyona başvurmuş demektir ve gerçek kişilerin bu yayında görünmedikleri anlamına gelir. Buna göre yalnızca bir el görünümü, çizgi karakterler, telefon gibi eşya kullanımı bu tür anlatım şeklinde örnektir. Bilimsel kanıt alanında uzman kişilerin (doktor, avukat, STK görevlisi) bilgilendirmelerini içeren yayınlara dahil olmaktadır. Sözel kanıt ise alanında uzman olmayan ancak belirli sempatikliğe ve özendiriciliğe sahip kimselerin (halktan bir kişi, ünlü, politikacı) söylemlerini içeren yayınlara dâhildir. Buna göre;

Araştırma sorusu 13: Kadına yönelik şiddet temalı yayınlarda mesajın veriliş şekli nasıldır?

Kamu spotu ve sosyal reklamlarda özellikle kadına yönelik şiddeti durdurmak için temel amaçlardan bahsedilebilir. Bu amaçlar, literatürde en net hali ile: bilgi verme, ikna etme ve hatırlatma olarak özetlenebilir (Kotler, vd., 1999, s.795). Kadına şiddeti önlemek ve bu bağlamda bir potansiyel davranışı durdurabilmek, bir davranış değişikliği amacı gütmektedir. Davranışta değişiklik yaratabilmek için ise ikna etme yönteminin, bilgi verme ve hatırlatmadan daha etkili olduğunu tahmin edilmektedir. Ancak bilgilendirme ve hatırlatma, sürekli olarak görsel medyada tekrarlandığı takdirde bireylerde konu ile ilgili farkındalık oluşturma bakımından da önemlidir. Zalluhaloğlu (2015) Türkiye'deki kamu spotlarını incelediği çalışmasında spotların genellikle (\%48) bilgilendirme amacı güttüğünü göstermiştir. Dolayısıyla çalışmanın son araştırma sorusu şu şekildedir;

Araştırma sorusu 14: Kadına yönelik şiddet temalı yayınlarda verilen mesajın amacı nedir? 


\section{Bulgular}

Araştırmaya 58 adet kamu spotu ve 6 adet sosyal reklam dahil olmuştur. Araştırmanın bulgularına kadına yönelik şiddet temalı medya faaliyetlerinin yayınlandığı yıllar ve yayım süreleri incelenerek başlanılmıştır. Buna göre Kadına Yönelik şiddet temalı medya faaliyetleri en sık 2015 $(\% 18,8)$ ve $2019(\% 14,1)$ yıllarında gösterilmiştir. Buna göre son 5 sene içerisinde kadına yönelik şiddeti konu eden yayınların arttı̆̆ı bu yöndeki çabanın da arttığına işaret olabilir. Araştırmaya dahil olan yayınların süreleri ise en sık oranda 45 saniye (\%20,3) ile 29 dakika (1740 saniye; $\% 9,4)$ olmaktadır. 29 dakika süreli yayınlar sosyal reklam niteliğindedir.

Tablo 2. Kampanyanın türü frekans analizi sonuçları

\begin{tabular}{lll}
\hline Kampanyanın Türü & FREKANS & O \\
\hline Kamu spotu & 58 & 90,6 \\
Sosyal reklam & 6 & 9,4 \\
TOPLAM & 64 & 100 \\
\hline
\end{tabular}

Araştırmaya dahil olan yayınlar genellikle Aile ve Sosyal Politikalar Bakanlığı tarafından yayınlanmıştır. Bu tür yayınlar bakanlık hariç, medya kuruluşları ve çeşitli, birlik, dernek ve vakıflar tarafından yayınlandığı da gözlemlenmektedir. Özellikle "İçimizden Birileri" ve "Suç Bende Değil" isimli sosyal reklam serileri TRT tarafından izleyicilere sunulmuştur. Genelde 45 saniyelik ve çoğunlukla 2019 yılında gösterilmiş kamu spotları ise en çok oranda Kadın ve Demokrasi Derneği (KADEM) önderliğinde yayınlanmıştır. Kolluk kuvvetlerine ait (Jandarma) kamu spotu ise bilgilendirme amaçlı olmuştur. Çoğu yayın bakanlıkların onayı ile gerçekleştiği için medya kuruluşlarının, birlik, dernek ve vakıfların isimleri yayının sonunda beraber bilgilendirme amaçlı dikkatli izleyiciler için verilmiştir. Bazı durumlarda ise yayın sonrası kurum özellikle ismini vurgulamıştır.

Kamu spotu ve sosyal reklamlarda verilen mesaj çoğunlukla şiddeti hatırlatma amaçlı $(\% 48,4)$ olmuştur. Hatırlatıcı mesajlar toplumda şiddetin hali hazırda bilindiğini göstermekte ve şiddetin zararlarını bir kez daha izleyiciye hatırlatarak caydırıcı olma amacı gütmektedir. Bilgilendirme mesajları ise şiddet sonrası ne yapılması gerektiği konusunda ge- 
rekli adımları (ilgili kuruma telefon etme, mobil uygulamasını uygulama, kolluk kuvvetlerine ulaşma, vd.) göstermektedir.

Tablo 3. Kurum ismi frekans analizi sonuçları

\begin{tabular}{lll}
\hline Yayımlayan Kurum & FREKANS & ORAN (\%) \\
\hline Medya Kuruluşu & 15 & 23,4 \\
Bakanlık & 33 & 51,6 \\
Kolluk Kuvvetleri & 1 & 1,6 \\
Birlik/Dernek/Vakıf & 12 & 18,8 \\
Belediye/Valilik & 3 & 4,7 \\
TOPLAM & 64 & 100 \\
\hline
\end{tabular}

İkna edici mesajların sıklığı bilgilendirici mesajlar ile benzer oranda çıkmıştır. Dolayısıyla şiddetin doğuracağı yıkıcı sonuçların izleyiciye hatırlatılmasının, şiddet uygulamamaya direkt olarak ikna etmekten daha sık başvurulan bir aktarım yöntemi olduğu gözlemlenmektedir. Araştırmaya dahil olan kamu spotu ve sosyal reklamlarda bu durumun örnekleri görülmüştür. Örneğin Aile İçi Şiddet ile ilgili bir kamu spotu, şiddete uğramış bir kadın figürün, hastane önünde bir bankta ağlayarak oturduğunu gösterir. Bu spot şiddetin yıkıcı etkisini hatırlatarak aslında bir yandan izleyiciyi şiddetin uygulanmaması gereken bir davranış olduğuna ikna da etmektedir. Burada davranış kalıbı izleyiciye dikte ettirilmeden şiddetin yıkıcılığı hatırlatılmış; izleyicinin bu mesajı anlaması ve dolayısıyla kendisinin şiddet göstermemeye ikna olması amaçlanmış olabilir.

Tablo 4. Mesajın amacı frekans analizi sonuçları

\begin{tabular}{lll}
\hline Mesajın Amacı & FREKANS & ORAN (\%) \\
\hline Bilgi Verme & 19 & 29,7 \\
İkna Etme & 14 & 21,9 \\
Hatırlatma & 31 & 48,4 \\
TOPLAM & 64 & 100 \\
\hline
\end{tabular}

Güvenilir bir mesajın veriliş şekli, şiddeti önleyici tema ile beraber, en çok hayattan bir kesit sunularak $(\% 34,4)$ ve sözel kanıt kullanılarak $(\% 34,4)$ anlatılmıştır. Hayattan kesitte en çok aile yaşantısından örnekler verilmişken (örneğin, KADEM'in "Evdeki şiddet hapiste biter" isimli spot yayımı), sözel kanıt genelde ünlü figürlerin sözlü olarak şiddet karşıtı söylemlerini içermiştir. Bu bağlamda ünlü kullanımı ayrı bir kod 
halinde sunulmuştur, çünkü anlaşılmalıdır ki çoğu ünlünün kadına şiddet çalışmaları ile ilgisi yokken kamu spotunda boy göstermesi, beğenilirlik içeren bu bireylerin davranışlarını örnek alan izleyicilerin de şiddeti kınayacaklarını varsaymıştır (örnek, "Yarım kalma" spotu). Ancak bazı sözel kanit içeren spotlar ünlü kullanmadan da yapılabilir (örnek, "Kadına şiddete karşı sıfır tolerans" ve "Korkma Unutma" (\#Şiddeti Sen Durdurabilirsin). Duygu ve görüntü kullanan, yani daha çok animasyon, şekiller, grafikler, vd. içeren yayınlar üçüncü sırada sıklıkta hazırlanmıştır. Bu tarz yayınlarda verilen mesaj bilgilendirme amaçlı olmaktadır. Bilimsel kanıt içeren yayınlar en az sıklıkla $(\% 6,3)$ görülmüştür. Bilimsel kanıt, bilim insanlarının bilgilendirici içeriklerle şiddeti açıkladıkları yayımlardır. Bu tür yayımlara örnek Bakanlığın 2005 yılında yayımladığ 1 "Aile içi şiddete son" isimli spot olabilir. Unutulmamalıdır ki bilimsel kanıt içeren yayımlar, herhangi bir istatistik, veya bilimsel bilgi içerdiği takdirde bilimsel kanıt ismi ile kodlanmıştır. Konu hakkındaki görüş, bildiri belirten bireyleri içeren kamu spotları ise genellikle sözel kanıt ismi ile kodlanmıştır. Ülkemizde yaşanan şiddet vakalarının sıklığı ortada iken ve şiddet hakkında konuşacak pek çok bilirkişi ve bilim insanı bulunmasına rağmen; “... sorunun temelinde yer alan eşitsiz güç ilişkilerinin zihinsel, sosyolojik, psikolojik, ekonomik nedenleri göz ardı edilmektedir." (Umunç, 2019, s.1331). Bu durum, bahsi geçen bir göz ard1 durumu olma olasılı̆̆ına karşın, kısa ve çarpıcı yapımların doğasında olan mesajın endirekt yol ile izleyiciye ulaşmasının önüne geçebilir. Örneğin bir utanma veya korku duygusuyla şiddetin zararlı olduğu kısa ve etkin şekilde izleyiciye aktarılacakken, bir bilim insanının konu hakkındaki konuşması dakikalar sürmektedir. Buna örnek olarak "İçimizden Birileri" isimli spot serisi verilebilir. Dolayısıyla özellikle kamu spotu yayınlarının doğası gereği bu yayınların az sıklıkta bilimsel kanıt içermesi ihtimal dahilindedir. Sosyal reklamlar ise tıpkı belgeseller gibi, bilimsel kanıta en çok ihtiyaç duyacak yayın çeşidi olmaktadır. Sosyal reklamlar daha yaygın olması ve ana akım medyada gösterilmesi, bu bağlamda hem bilimsel kanıt ihtiyacını giderecek, hem toplumu bilinçlendirecek, hem de şiddetin en başta önlenmesinde katkı sağlayacaktır. 
Tablo 5. Mesajın veriliş şekli frekans analizi sonuçları

\begin{tabular}{lll}
\hline Mesajın Veriliş Şekli & FREKANS & ORAN (\%) \\
\hline Hayattan Kesit & 22 & 34,4 \\
Yaşam Tarzı & 5 & 7,8 \\
Fantezi & & \\
Yalnızca Duygu veya Görüntü Kullanımı & 11 & 17,2 \\
Bilimsel Kanıt & 4 & 6,3 \\
Sözel Kanıt & 22 & 34,4 \\
TOPLAM & 64 & 100 \\
\hline
\end{tabular}

Tablo 6. Mesaj kaynağının özelliği frekans analizi sonuçları

\begin{tabular}{lll}
\hline Mesajın Kaynağının... & FREKANS & ORAN (\%) \\
\hline Uzmanlığı & 12 & 18,8 \\
Güvenilirlik & 27 & 42,2 \\
Beğenilirlik & 24 & 39,1 \\
TOPLAM & 64 & 100 \\
\hline
\end{tabular}

Yayınlarda mesajın genellikle negatif bir tona sahip olduğu $(\% 60,9)$ görülmektedir. Negatif ton ile hatırlatıcı yayınlar birbiri ile örtüşmektedir. Nötr ton $(\% 32,3)$ kullanan mesajların çoğunlukla bilgilendirici amaçlı mesajlar içerdiği düşünülebilir.

Tablo 7. Mesajın tonu frekans analizi sonuçlarn

\begin{tabular}{lll}
\hline Mesajın Tonu & FREKANS & ORAN (\%) \\
\hline Negatif & 39 & 60,9 \\
Pozitif & 4 & 6,3 \\
Nötr & 21 & 32,8 \\
TOPLAM & 64 & 100 \\
\hline
\end{tabular}

Yayınlarda kullanılan müzik ve renk, yayının duygu durumunu ve anlatış tarzını oldukça etkileyen bir faktördür. Yayınların \%64,1'i müzik kullanmıştır. Mesajın tonunun en çok negatif oranda kullanıldı ̆̆ı sonucu da dikkate alındığında, kullanılan müziğin hüzünlü bir müzik olduğu kanısı ortaya çıkacaktır. 
Tablo 8. Müzik varlı̆̆ı frekans analizi sonuçları

\begin{tabular}{lll}
\hline Müzik Varlığı & FREKANS & ORAN (\%) \\
\hline Var & 41 & 64,1 \\
Yok & 23 & 35,9 \\
TOPLAM & 64 & 100 \\
\hline
\end{tabular}

64 yayından yalnızca 4 'ü siyah beyaz çekilmiştir. Renkli yapımlar, genelde hayattan kesit sunan yayınların sıklığı düşünüldügünde yerinde bir kullanım tarzı olmuştur.

Tablo 9. Renk varlığı frekans analizi sonuçlar

\begin{tabular}{lll}
\hline Renk varlığı & FREKANS & ORAN (\%) \\
\hline Renkli & 60 & 93,8 \\
Siyah-Beyaz & 4 & 6,3 \\
TOPLAM & 64 & 100 \\
\hline
\end{tabular}

Dillard ve Peck (2000, s.461) kamu spotlarının istenen duyguların dışında farklı duyguları da açığa çıkarabileceklerini tartışmışlardır. Çalışmada yer alan yayınlar genelde farklı duyguları içermektedir. Bir yayında elbette ki birden çok duygu barınmaktadır. Ancak kodlama açısından kolaylık sağlamak amacıyla en baskın duygu her yayın için düşünülmüş ve o baskın duygu kodlanmıştır. En sık nötr yani baskın duygu içermeyen yayınlar $(\% 39,1)$ gözlemlenmiştir. Bilgilendirme amaçlı mesajların $(\% 29,7)$ sıklığı düşünüldüğünde, herhangi baskın duygu içermeyen yayınların en sık gözlenmesi normaldir. Bunun sebebi bu tarz yayınların bilgilendirici ve hatırlatıcı olmalarıdır. Bunun dişında hüzün duygusu ikinci sıradadır $(\% 37,5)$. Kadına yönelik şiddet temalı yayınlar söz konusu olduğu için bu duygunun baskın şekilde ortaya çıkmış olması normaldir. Araştırmaya dahil olan yayınlarda korku ve öfke duygularının çok baskın şekilde ortaya çıkmamış olduğuna not düşülmelidir. Utanma duygusu ise 6 adet kamu spotunda gözlemlenmiştir. "Hangi Yüzle" isimli kamu spotu, "Başkalarına göstermekten utanç duyduğun bir yüzün var. Sevdiklerine göstermekten çekinmiyorsun. Sevdiklerine hangi yüzle bakıyorsun?" ifadesini içermektedir. Bu spotta özellikle utanma duygusu vurgulanmıştır. 
Tablo 10. Duygu kullanımı frekans analizi sonuçları

\begin{tabular}{lll}
\hline Duygu Kullanımı & FREKANS & ORAN (\%) \\
\hline Utanma & 6 & 9,4 \\
Sevgi & 1 & 1,6 \\
Öfke & 4 & 6,3 \\
Hüzün & 24 & 37,5 \\
Korku & 4 & 6,3 \\
Nese/Coşkunluk & 25 & 39,1 \\
TOPLAM & 64 & 100 \\
\hline
\end{tabular}

Vodinalı ve Akıncı $(2019$, s.49) çalışmasında kamu spotlarının şiddet vakası yaşandıktan sonraki durumda ne yapılacağını bilgilendirmenin dışında, şiddet vakasını önleyici özellikler barındıran kamu spotlarına daha çok ihtiyaç olduğunu vurgulamıştır. Bu çalışmada araştırmaya dahil olan yayınlar genellikle üçüncül önlem inisiyatifi altında $(\% 73,4)$, şiddet oluştuktan sonraki aşamalarda yapılması gerekeni izleyiciye göstermektedir. Bu durumda üçüncül önlemler bir kadının eşinin hali hazırda şiddete meyilli olmasını bilmesi ve erkeğin de şiddet türlerinden birini göstermiş olması durumunda şiddetin tekrar etmemesi için uğraşmaktadır. Örneğin "Evdeki Şiddet Hapiste Biter" isimli kamu spotu çalışmasında eşine şiddet uygulayan bir erkeğin hapse gireceğini korku ve öfke öğeleri kullanarak net şekilde açıklar. Mesajın amacının bilgilendirici olduğu ve herhangi baskın bir duygu içermeyen yayınlar ise birincil önlem inisiyatifi altında gerçekleşmiştir. Böylece şiddet daha oluşmadan neler yapılmalı, hangi kurum ve kuruluşlar şiddet sonrası yardımcı olabilir, hangi durumlarda şiddet önlenebilir konusunda bilgiler verilmiştir.

Tablo 11. Önlem inisiyatifi frekans analizi sonuçları

\begin{tabular}{lll}
\hline Önlem İnisiyatifi & FREKANS & ORAN (\%) \\
\hline Birincil & 14 & 21,9 \\
İkincil & 3 & 4,7 \\
Üçüncül & 47 & 73,4 \\
TOPLAM & 64 & 100 \\
\hline
\end{tabular}

Yayınlarda izleyiciyi teknoloji kullanmaya teşvik etmek önlem inisiyatiflerinin uygulamaya geçirilmesi bakımından yerindedir. Teknolojiden kasit, mobil uygulama ve telefon olmaktadır. Ne var ki, teknoloji kullanmaya aktif şekilde teşvik eden yayınların oranı \%18,8'dir. Teknolojik yenilik açısından en yeni atılım KADES olmuştur. KADEM derneği, 
kadınlara acil durumlarda kullanabilecekleri KADES isimli bir mobil uygulama sunmuş, uygulama hakkında bilgilendirmiş ve kullanmaya teşvik etmiştir.

Tablo 12. Teknoloji önerisi sunma varlı̆̆ frekans analizi sonuçları

\begin{tabular}{lll}
\hline Teknoloji Önerisi Sunma Varlığı & FREKANS & ORAN (\%) \\
\hline Var & 12 & 21,9 \\
Yok & 52 & 4,7 \\
\hline
\end{tabular}

Mesajı çoğunlukla bir dış ses vermiştir. Dış ses erkek veya kadın olabilmektedir. Dış ses, telefon numarası, acil yardım hattı gibi bilgilendirici mesajları ve/veya kamu spotunun amacını açıklayan kısa bir cümleyi izleyiciye aktarmaktadır. Ünlü kişi kullanımı, genelde "Kadın Hayattır" spotunda olduğu gibi, kadının önemini açıklayan erkek bireylerin kullanıldığı yayımlar olmuştur. Ayrıca hayattan birisi olarak tanımlanan toplumdaki bireylere benzer bir birey de yayınlarda çokça kullanılmıştır. Buna bir örnek, "kadına şiddet insanlığa ihanettir" spotundaki toplumun çeşitli kesimlerinden erkek bireylerin konuşma yaptıkları spot olabilir. Uzman kişiler, TRT tarafından hayata geçirilen "İçimizden Birileri" isimli yayımlarda daha sık kullanılmıştır. Uzman kişiler bu gibi yayımlarda gerekli bilgileri diğer oyunculara veya izleyiciye aktaran konumundadır.

\begin{tabular}{lll} 
Tablo 13. Mesajın kim tarafından verildiği frekans analizi sonuçları & \\
\hline Mesajın Kimin Tarafından Verildiği & FREKANS & ORAN (\%) \\
\hline Ünlü & 17 & 26,6 \\
Diş ses & 25 & 39,1 \\
Uzman & 3 & 4,7 \\
Hayattan birisi & 15 & 23,4 \\
Hiçbiri & 4 & 6,3 \\
TOPLAM & 64 & 100 \\
\hline
\end{tabular}

Yayınlarda en çok oranda kadın, erkek, çocuk bir arada kullanılmıştır. Özellikle çocuklar, empati ve duygu yoğunluğuna yol açabileceği için genellikle şiddeti duyan veya gözlemleyen konumunda tutulmuştur. Yayınlarda erkeğin rolü farklı şekillerde gözlemlenmiştir. Öncelikle erkek ataerkil feodal toplum yapısı ile paralel şekilde gösterilmiştir. Bu tür erkek figürleri genelce üçüncül önlem inisiyatifi kullanılan yayınlarda gözlemlenmiştir. Bu durum da şiddete meyilli erkeklerin yapısını açı- 
lar. Bir başka gözlem ise yayınlarda gösterilen ünlü ve uzman erkeklerin şiddeti önlemek isteyen tavırda ve bu konuda iletişimin nasıl olması gerektiğini erkeğe öğretici pozisyonda olmasıdır. Örneğin “Şiddetin Bahanesi Olmaz" isimli yayında ünlü erkek figürleri şiddet uygulamak için hiçbir bahanenin temel oluşturamayacağını açıklar. Bununla beraber "Kadına Şiddet İnsanlığa İhanettir" yayınlarında da Türkiye'nin dört bir yanındaki erkek figürlerinin kadını öven ve yücelten söylemleri gösterilmiştir. Araştırmaya dahil olan diğer yayınlardan bazıları ise yalnızca kadın figürleri konuk etmiştir. Kadın figürler bu yayınların bilgilendirici amaçlı olanlarında güçlü, ne yapması gerektiğini bilen bir tavır alırken, hatırlatıcı ve ikna etme amaçlı yayınlarda korkmuş, çaresiz, yalnız şekilde görünmektedir.

Hayvanların kullanımı ise spotlarda çok azdır. En yakın zamanda kurt, ayı ve penguenlerin "aile" yaşamlarını konu alan "Cins var Cins var" isimli KADEM tarafından yayımlanmış spot, hayvanların hayatı üzerinden insanların şiddetsiz ve kadını koruyup kollayıcı bir tavırda yaşaması gerektiğini vurgulamıştır. Bu esnada hayvanın ailesini koruduğu ve bahsedilen hayvanların ne kadar güçlük altında veya ne kadar güç sahibi oldukları vurgulanır. Araştırmacıya göre bu "güç" olgusu aslında insan erkeğine atıftır. Erkek de ayı, kurt veya penguen gibi güçlü yapıdadır, ancak kadınına saldırmaktadır. Bu yanlıştır. Bu mesaj, izleyicilerin hayvanlardan üstün ırk olan insanlık adına utanmalarını sağlayabilmekle beraber, bir ders verme amacı taşıdığı yorumu çıkarılabilir.

Tablo 14. Kişi kullanımı frekans analizi sonuçları

\begin{tabular}{lll}
\hline Kişi Kullanımı & FREKANS & ORAN (\%) \\
\hline Kadın & 16 & 25 \\
Erkek & 8 & 12,5 \\
Çocuk & 3 & 4,7 \\
Karma & 29 & 45,3 \\
Hayvan & 3 & 4,7 \\
Hiçbiri & 5 & 7,8 \\
TOPLAM & 64 & 100 \\
\hline
\end{tabular}

Araştırmaya dahil olan kamu spotlarının çoğunda kadın figürü varlığ1 gözlemlenmektedir. Üstteki araştırma bulgusuna bağlı olarak kadınlar bazen tek başlarına, bazen ise erkek, çocuk ve diğer kadınlarla beraber yayımlara dahil olmuştur. Bu frekans analizinde vurgulanmak istenen 
kadın figürünün kullanılmadığı durumlardaki kamu spotunun durumudur. Kadın figürlerinin kullanılmadığı spotlarda ya bilgilendirici amaçlı olarak yalnızca animasyonlar ve cümleler yer almakta, ya da yalnızca erkekler yer almaktadır. Kadın kullanımının kamu spotu içerisinde daha dramatik bir etki yaratabileceği düşünülebilir.

Tablo 15. Kadın kullanımı varlığı frekans analizi sonuçlan

\begin{tabular}{lll}
\hline Kadın Kullanımı Varlığı & FREKANS & ORAN (\%) \\
\hline Var & 44 & 68,8 \\
Yok & 20 & 31,3 \\
TOPLAM & 64 & 100 \\
\hline
\end{tabular}

Literatürde kamu spotlarında görsel efektlerin (grafik animasyon, vd.) bir çalışmada \%38 oranında (Bilis, 2014), bir başka çalışmada ise \%13,1 oranında kullanıldığ görülmüştür (Zalluhoğlu vd., 2015). Bu çalışmada kullanılan görsel ögeler içeren yayınlar (\%17) genelde animasyon, çizgi karakterler, şemalar ve grafikler halinde kullanılmıştır. Bu tarz animasyon spotları genelde herhangi negatif duygu ifşa etme amacından çok, toplumu bilgilendirme amacı taşımaktadır.

\section{Tartışma ve Sonuç}

Şiddet dünyada olduğu gibi, Türkiye'de de toplumsal bir sorundur. Yapılan bir çalışma, kadınların \%35'inin hayatları boyunca eşlerinden en az bir kez istismar gördüğünü göstermiştir (Altınay ve Arat, 2008, s.79). Bu çalışmadan çıkan sonuçlarda, kamu spotlarının genelde dış ses tarafından verilmiş, verilen mesajın şiddetin yıkıcılığını hatırlatıcı yapıda olmuş ve verilen mesajda genellikle toplumdan benzer yapıda bireylerin oyunculuğunda hayattan bir kesit sunarak aktarılmıştır. Hayattan bir kesit sunma yönteminde toplumu temsil eden karakterler çeşitli rollerde oynayarak şiddetin yıkıcılığını ele almıştır. Bu tarz yayınların yanı sıra, sözel kanit olarak tabir edilen, toplumun her kesiminin sevdiği ve benimsediği topluma mal olmuş kişiler şiddet hakkında mesaj vermiş ve bu bireylerin beğenilirlik yolu ile mesajlarının daha dikkatle dinleneceği öngörülmüştür. Genellikle spot yayınlarının sonlanmasına yakın saniyeler içerisinde bir "dış ses" verilmek istenen mesajı ve bu doğrultuda 
atılması gereken adımları belirtmiş, mesaj sonunda ise yayını gerçekleştiren kurum veya kuruluşların isimleri gözükmüştür. Kadına yönelik şiddet temalı yayınların temelinde kadın figürlerinin çeşitli şekillerde görüntülenmesi gözlemlenmiştir. Araştırmaya dahil olan kamu spotlarının, kadınları görsellerinde çok kullandıkları, bunun yanı sıra, erkek ve çocuk karakterleri de anlatmak istediği hikayeye dahil ettiği görülmüştür. Müzik ve renk kullanımı dramatik düzeyde olup genellikle hüzün duygusu aşılanmıştır. Hüzün duygusunun yanı sıra utanma duygusunun da özellikle erkek tarafından hissedilmesi gereken bir duygu olduğunu alt mesaj olarak devşiren yapımlar da mevcuttur. Araştırmanın sonuçlarına bakıldığında toplumsal cinsiyet eşitsizliğini işaret eden pek çok çıktı bulunmuştur. Umunç'un $(2019$, s.1330) yaptığ adet kamu spotu incelenmiş ve bu spotlarda kadına yönelik şiddeti çözmek amaciyla erkek davranışlarına daha çok odaklanıldığı görülmüştür. Bu da erkek ile kadın eşitliği, ataerkil toplum yapısının törpülenmesi gibi unsurları içermeyip yalnızca erkeğin davranışlarını değiştirmesi gerektiği konusuna odaklanılmıştır. Kadın, bu spotlarda yine itaatkâr olan figür olarak betimlenmiştir. Yazar, kamu spotlarının şiddetin temelinde ne olduğunu sorgulayan bir mesaj ve çözüm önerisi içermediğini belirtmiştir. Benzer şekilde şimdiki çalışmada da erkek, ataerkil feodal yapıya uygun olarak resmedilmiştir. Karaca ve Papatya (2011, s.496-497) 1990 ve 2009 yılları arasında gösterilen kadınları içeren TV reklamlarının içerik analizini gerçekleştirmiştir. Sonuçlar, kadınların cinsiyet rolünü stereotiplerinin örneği olarak evin içinde gösterildiğini göstermiştir. Umunç (2019, s.1331) da benzer şekilde kadın erkek eşitliğinin vurgulandığı ve kadının ikincil gösterilmediği bir medya dilinin, kadına yönelik şiddet kapsamında faydalı olacağını öngörmüştür. Bu bağlamda bu çalışmada da kadın figürleri, mesaj verme gayesinde olan ünlü bireylerin dışında, hikayenin içinde oldukça güçsüz ve aciz gösterilmiştir. Kadının güçlü, kendinden emin ve şiddet karşısında cesaretli durma kabiliyetinin vurgulanacağı kamu spotları toplumdaki konu hakkındaki utanmanın ve sindirilmişliğin giderilmesi açısından daha kolay olacaktır. Unutulmamalıdır ki, kamu spotu ve sosyal reklam gibi sosyal pazarlama kampanyalarının dikkatli bir şekilde yürütülmesi; bazı durumlarda insanları etkilemek için kullanılan içeriğin istenmeyen bir şekilde izleyiciler tarafından olumsuz tepki vermelerine yol açmasını önleyebilir. Bu bağlam- 
da, araştırmacılar bazı kampanyaların "bireysel kimliklere ve güç ilişkilerine doğal olarak bağlı olarak değişen ve derin köklü ideolojiler, uygulamalar ve sosyal normların sıklıkla şiddet, direnç ve geri tepme" ile sonuçlandığını literatürde savunulmuştur (Haylock, Cornelius, Malunga, Mbandazayo, 2016, s.240). Dolayısıyla toplum yapısına bağlı bir erkek figürünün kamu spotlarında resmedilmesi, aynı zamanda bu erkek tipinin kadına zarar verdiğinin açıkça gösterilmesi ve davranışın uygunsuzluğunun vurgulanması bu bağlamda kamu spotlarını izleyen kişiler tarafından tepki ile karşılanmayacaktır. Bunun nedeni, bu feodal yapıya uygun erkeğin toplum tarafından bilinmesi ve bu tür maskülen özellikleri ile öne çıkan erkeklerin şiddete daha meyilli olduklarının kabulündendir. Ancak bu kabul durumu toplumdaki erkek-kadın rollerinin normalleşmesinin de bir kanıtıdır ve değişim ancak normalleşmenin ötesine geçildiğinde gerçekleşecektir. Gelecek çalışmalardaki sosyal pazarlama kampanyaları şayet bu tür erkek figürlerini eşlerine, sevgililerine, kızlarına karşı daha yumuşak başlı olarak gösterdiği takdirde Haylock ve arkadaşlarının (2016) bahsettiği dirençle karşılaşılabilir. Bu direnci kırmak ise akademisyenlerin, toplumbilimcilerin, hükümetlerin ve medya kuruluşlarının birlikte çalışması sonucu kırılabilir. Ne var ki, Türkoğlu (2013, s.156), en çok izlenen TV filmlerinin ve TV şovlarının kadınlara karşı şiddet içerdiğini çalışmasında göstermiştir. Araştırmacıya göre özellikle bu sahnelerin izleyiciyi eğlendirmeyi amaçladığı için arka planda kahkaha etkilerinin olması durumu ise vahimdir. Bu filmleri ve şovları izleyen insanların yavaş yavaş şiddete karşı uyuşuyor olması ve normal bir günlük olay olarak görmeye başlamaları toplumsal öğrenmeye örnektir. Toplumsal öğrenme kuramı, televizyondaki şiddet içerikli programların izleyicilerde anti-sosyal ve saldırgan karakter özelliklerini ortaya çıkaracak şekilde düzenlendiğini savunmaktadır. Toplumsal öğrenme kuramına göre bireyler, diziler, filmler ve diğer televizyon şovlarında izledikleri karakterleri içselleştirerek onları kahraman ilan eder ve o karakterlerin şiddet uygulayarak başarılı, güçlü, zeki, gibi meziyetlerini kendine uyarlayabilmek için kendi de şiddet uygulamaya başlar (Bandura, 1973, s.79; aktaran Dilber, 2014, s.62). Dolayısıyla medyadaki yayınların cinsiyet eşitsizliğini ortadan kaldıracak şekilde ve şiddet öğelerini en aza indirecek şekilde yayınlar ortaya koymaları toplu- 
mun şiddetsizliği ve eşitliği yeniden öğrenebilmesi ve benimseyebilmesi için hayati derecede önemlidir.

Bu çalışmada kullanılan araştırma yönteminin bazı sınırları bulunmaktadır. Öncelikle, içerik analizi yöntemi iki farklı olgu arasındaki nedensel ilişkileri ölçememektedir (Berg, 2001, s.259). Bu çalışmada kullanılmış tek analiz ise frekans analizidir. Bunun dışında, içerik analizi yöntemi sadece kayıtlı bilgilerden elde edilen bilgilerin ışığında uygulanmaktadır. Çalışmada, yalnızca kamu spotu reklamları hakkındaki bilgiler toplanıp analiz edilmiştir. Çalışmada ortaya atılan araştırma soruları ve soruları açıklamak için literatürden toplanan kriterler, araştırmacı tarafından literatür taraması sonucunda elde edilmiştir. Literatürde kullanılabilecek pek çok farklı kriterin çalışmaya eklenmemiş olması bu çalışmanın bir başka kısıtı olmaktadır. Sonraki çalışmalar farklı araştırma soruları ışığında farklı sonuçlar alabilecektir. Bu bağlamda kazanç-zarar çerçevesine sahip mesajlar kamu spotu ve sosyal reklamlarda nasıl işleniyor görülebilir. Literatürde yer alan bireysel karar verme modeline göre, insanlar bir davranışı uygulayarak elde edecekleri kazançlarla benzer şekilde o davranıştan elde edecekleri kayıpların arasında tanımlanan sonuçları birbirinden ayırmaktadır (Tversky ve Kahneman, 1991). Mesaj iletişimi, şiddetsizlik temalı bir davranışı (kazanç çerçeveli bir itiraz) benimseyerek sağlanan faydaları açıklayabilir veya şiddet temalı bir davranışı (zarar çerçeveli bir itiraz) kaybedilen unsurlara yoğunlaşarak anlatabilir. Özetle verilen mesaj şiddetin zararları şeklinde incelenebilir. Hangi spotun veya sosyal reklamın daha etkin olduğu ise farklı nitel ve nicel araştırma yöntemleri ile irdelenebilir. Kadına yönelik şiddet kapsamında şiddetin dört türü (cinsel, fiziksel, psikolojik, ekonomik) ayrıca kodlanması gereken önemli bir unsurdur. Çalışmanın bir diğer kısıtı, içerik analizine kadına yönelik şiddet türlerinin kodlamaya dahil edilememesidir. Bunun sebebi, araştırmaya dahil olan yayınların bazılarının vurguladıkları şiddet türünü kategorileştirmemiş olmalarıdır. $\mathrm{Bu}$ çalışmada irdelenen kamu spotu ve sosyal reklamların kadına yönelik şiddeti durdurmayı amaçlarken en çok aile içi şiddet üzerinde durulduğu görülmüştür. Aile içi şiddet çok yaygın ve halk sağlığını ciddi şekilde tehdit eden bir sorun olmaktadır (Erdoğan, Aktaş ve Bayram, 2009, s.809). Örneğin çoğu kamu spotu aile içi şiddete vurgu yaparken, dört şiddet türünden biri veya birden fazlası olabileceği için yine şiddet türle- 
ri arasında ayrıştırma olmamıştır. Şiddete karşı olan farkındalığı artırmak için kullanılan tüm bu yayınların yanı sıra, şiddet türleri hakkında da halkı bilinçlendirecek, özellikle psikolojik ve ekonomik şiddet gibi görünür izler bırakmayan şiddet türlerini açıklayacak yayınların gelecekte izleyiciye sunulması son derece yararlı olacaktır (Umunç, 2019). 
EXTENDED ABSTRACT

\title{
Content Analysis of Public Service Announcements That Focus on Violence Against Women
}

\author{
Begüm Yetişer
}

9 Eylül University

Violence against women is a social problem in Turkey, as well as in the World. There are four main types of violence against women and these are: Psychological, economical, physical and sexual. Each type of violence is severe and need to be taken seriously in order to stop/reduce violence against women within a society. Various organizations work directly or indirectly with women in the fight against violence. For example, civil society organizations and governmental organizations carry out various actions to help abused women, such as providing physical and psychological help and accomodation. In addition, these organizations help to empower women, educate children and raise awareness of the society against violence. In addition to the efforts of these organizations, it is very important to use mass communication correctly in order to raise awareness about violence against women and to give proper information to the society.

If used correctly, mass media can offer a solution for all kinds of social problems. There are also a number of public service announcements created on the topic of violence against women. In particular, public service announcements created by various institutions or organizations are an important tool to raise awareness of the society on the subject of violence. Every step taken in the mass media to stop violence against women is very important as it is watched by large masses.

In literature, there are research papers that have examined the public service announcements and social advertisements that were created in Turkey. This study consists of public service announcements and social advertisements only on the topic of violence against women. Currently, Ministry of Family and Social policies, local governments and media organizations prepare various booklets, brochures, posters, videos via visual or written documents about violence agains women. In this study, 
public service announcements and social advertisements were examined via content analysis. The codings of the content analysis were chosen from the literature with a few new additions.

According to the results of the content analysis, the most frequent publications were created by the Ministy. In these broadcasts, it was observed that a negative message tone was most used. In these messages, mostly items were used to remind the gravity of violence. This ferocity is often demonstrated by the use of color and music. It has been observed that women, men and children as characters were usually shown together in public service announcements and social advertisements. These characters were parts of a story, showing slice of life. In this storytelling, the emotions of anger and sadness were the two most frequently used emotions. In addition, it has been observed that the feeling of embarrassment is one of the additional emotions used, especially directed towards male audience. The source of the message is most often described as a reliable source. Usually, a voice-over explained what can be done after violence.

The results of the content analysis showed that in general, it has been seen that female characters are generally shown as needy and sad. Furthermore, the messages to the female target audience were focused on the answers to the question of what can be done after violence. On the other hand, the messages targeted towards male audience emphasized that violence is a criminal sanction. In paralel with these affirmations, content analysis revealed that the messages most frequently focused on tertiary message type, which is one of the three (primary, secondary, tertiary) precaution types that aims to reach to audience in different ways. Specifically, tertiary precaution explains what can be done after the violence occurs. In this case, future studies could focus on what would be done to stop the violence before it occurs (primary precaution) and what to do to stop violence during the abuse (secondary precaution).

Content analysis also revealed that the storytelling often included the destructive effects of violence. Thus, the negative tone of message is conveyed. Future studies would include concepts such as the environment to be created to stop violence, the emotions to be felt, the empowerment of women, how men's behavior towards violence should change, and what will happen if they change. In this context, a more positive message 
tone with solutions to the problems at hand would be effective. Finally, as a result of content analysis, it was seen that public service announcements and social advertisements emphasized on the theme of domestic violence. In addition to domestic violence, future research would focus on other types of violence to raise awareness.

In the end, violence against women is a severe social problem which needs to be effectively communicated with the society. Thus, this study is an important study as it is one of the pioneering studies in the Turkish literature on violence against women and public service announcements.

\section{Kaynakça / References}

Akkuş, S., ve Yıldırım, Ş. (2018). Erkeklerin kadına yönelik fiziksel şiddet uygulamasına etki eden faktörlerin incelenmesi. Gaziantep University Journal of Social Sciences, 17(4), 1368-1388.

Altınay, A. G., ve Arat, Y. (2009). Violence against women in Turkey: A nationwide survey. Punto.

Altıparmak, İ. B. (2015). Kadına yönelik aile içi şiddetle mücadelede ŞÖNIM'lerin rolü: Ankara örneği. International Journal of Social Science, 36, 449-464.

Berg, B.L. 2001. Qualitative research methods for the social sciences. 4th Edition, Pearson, 75-76.

Bilis, A. E. (2014). Kamu hizmeti yayıncılı̆̆ının yeni eğilimi kamu spotları üzerine bir inceleme. I. Uluslararası Iletişim Bilimi ve Medya Araştırmaları Kongresi, 347-364,

Borzekowski, D. L., ve Poussaint, A. F. (2000). Common themes from the extremes: Using two methodologies to examine adolescents' perceptions of anti-violence public service announcements. Journal of adolescent health, 26(3), 164-175.

Bütün, M., Selçuk, M. , Akadal, E. ve Gülseçen, S. (2018). Kamu spotlarının etkililiği üzerine bir araştırma. Selçuk İletişim, 11(2), 273-291.

Cevher, E., ve Öztürk, U. C. (2015). İş yaşamında kadınların kadınlara yaptığ1 mobbing üzerine bir araştırma. Insan ve Toplum Bilimleri Araştırmaları Dergisi, 4(4), 860-876.

Chang, K. C., Jackson, J., ve Grover, V. (2003). E-commerce and corporate strategy: an executive perspective. Information $\mathcal{E}$ Management, 40(7), 663-675. 
Çalışkan, H., ve Çevik, E. İ. (2018). Kadına yönelik şiddetin belirleyicileri: Türkiye örneği. Balkan Sosyal Bilimler Dergisi, 7(14), 218-233.

Dilber, F. (2014). Kitle iletişim araçları ve suç olgusu. Karamanoğlu Mehmetbey Üniversitesi Sosyal ve Ekonomik Araştırmalar Dergisi, 2014(3), 60-66.

Dillard, J. P., ve Peck, E. (2000). Affect and persuasion: Emotional responses to public service announcements. Communication Research, 27(4), 461495.

Edelmann, R. J. (1985). Individual differences in embarrassment: Selfconsciousness, self-monitoring and embarrassibility. Personality and Individual Differences, 6(2), 223-230.

Erdoğan, S., Aktaş, A., ve Bayram, G. O. (2009). Violence experiences and coping attitudes in a sample of women who live in a shelter: a qualitative study. Journal of Human Sciences, 6(1), 807-824.

Ergeç N. ve Zateri İ. (2015). Kamu spotu örnekleminde medyada kadına şiddetin alımlanması, 1. Uluslararası Çukurova Kadın Çalışmaları Kongresi, Nisan, 381-387.

García-Moreno, C., Jansen, H. A. F. M., Ellsberg, M., Heise, L., ve Watts, C. (2005). WHO multi-country study on women's health and domestic violence against women. Geneva: World Health Organization, 204, 118.

Göçmen, T. L., ve Ayvaz, S. (2017). Kamu spotlarının göstergebilimsel yöntemle çözümlenmesi: Sağllk Bakanlığı örneği. Anadolu Üniversitesi İletişim Bilimleri Fakültesi Uluslararası Hakemli Dergisi, 25(2), 112-128.

Gülada, M. O. (2018). Korku çekiciliği kavramının trafik kazalarını konu alan kamu spotu reklamlarında kullanımı. Uluslararası Sosyal Bilimler Dergisi, 1(2), 131-143.

Hacettepe üniversitesi nüfus etütleri enstitüsü. (2015). Türkiye'de kadına yönelik aile içi şiddet araştırması. E.T.: 05 Mayıs 2020. http://www.hips.hacettepe.edu.tr/KKSATRAnaRaporKitap26Mart.pdf.

Haylock, L., Cornelius, R., Malunga, A., ve Mbandazayo, K. (2016). Shifting negative social norms rooted in unequal gender and power relationships to prevent violence against women and girls. Gender and Development, 24(2), 231-244.

Hsieh, H. F., ve Shannon, S. E. (2005). Three approaches to qualitative content analysis. Qualitative Health Research, 15(9), 1277-1288. 
Kamu spotu "Aile İçi Şiddet Son” (El Kızartmaca). 05 Mayıs 2020 tarihinde https://www.youtube.com/watch?v=oyQOlrzS8hc adresinden erişildi.

Kamu spotu "Aile İçi Şiddete Son Demek Yetmiyor". 05 Mayıs 2020 tarihinde https://www.youtube.com/watch? $v=8 \mathrm{cl}$ 6W0ar10 adresinden erişildi.

Kamu spotu "Aile İçi Şiddete Son" (8 Mart,2013) 1. Bölüm. 05 Mayıs 2020 tarihinde https://www.youtube.com/watch?v=IZM-_uHAptA adresinden erişildi.

Kamu spotu "Aile İçi Şiddete Son" (8 Mart,2013) 2. Bölüm. 05 Mayıs 2020 tarihinde https://www.youtube.com/watch?v=TwdWVXga39Y adresinden erişildi.

Kamu spotu "Aile İçi Şiddete Son" (8 Mart,2013) 3. Bölüm. 05 Mayıs 2020 tarihinde https://www.youtube.com/watch?v=WMJ3Wli-csI adresinden erişildi.

Kamu spotu "Aile İçi Şiddete Son" (8 Mart,2013) 4. Bölüm. 05 Mayıs 2020 tarihinde https://www.youtube.com/watch?v=WHXa44umhcI adresinden erişildi.

Kamu spotu "Aile İçi Şiddete Son" (8 Mart,2013) 5. Bölüm. 05 Mayıs 2020 tarihinde https://www.youtube.com/watch?v=zXAVv3kMJnA adresinden erişildi.

Kamu spotu "Aile İçi Şiddete Son" (8 Mart,2013) 6. Bölüm. 05 Mayıs 2020 tarihinde https://www.youtube.com/watch?v=LADI4ElB7Z8 adresinden erişildi.

Kamu spotu "Aile İçi Şiddete Son" (8 Mart, 2013) 7. Bölüm. 05 Mayıs 2020 tarihinde https://www.youtube.com/watch?v=eHiYOzlTIRo adresinden erişildi.

Kamu spotu "Aile İçi Şiddete Son" (8 Mart,2013) 8. Bölüm. 05 Mayıs 2020 tarihinde https://www.youtube.com/watch?v=NamkY5Jq2D4 adresinden erişildi.

Kamu spotu “Aile İçi Şiddete Son” ("Erkeksen Vurma, Kadınsan Susma”). 05 May1s $2020 \quad$ tarihinde https://www.youtube.com/watch?v=CDxyLUTqpuQ;

https://www.youtube.com/watch?v=NdY4hpoZtC0 adresinden erişildi.

Kamu spotu "Aile İçi Şiddete Son" ("Görünmez El”). 05 Mayıs 2020 tarihinde https://www.youtube.com/watch?v=FZfLgMYTI9c adresinden erişildi.

Kamu spotu "Aile İçi Şiddete Son" ("Hastane"). 05 Mayıs 2020 tarihinde https://www.youtube.com/watch?v=xZk4aOAqEM8 adresinden erişildi. 
Kamu spotu "Aile İçi Şiddete Son" ("SMS"). 05 Mayıs 2020 tarihinde https://www.youtube.com/watch?v=ftKyq7_1NJ8 adresinden erişildi.

Kamu spotu "Aile İçi Şiddete Son" ("Telefon Numarası"). 05 Mayıs 2020 tarihinde https://www.youtube.com/watch?v=iMXO5NCyxoM adresinden erişildi.

Kamu spotu "Aile İçi Şiddete Son" ("Yumruk"). 05 Mayıs 2020 tarihinde https://www.youtube.com/watch? $v=X b L g 5 B 3 l K 2 c$ adresinden erişildi.

Kamu spotu "Aile İçi Şiddete Son". 05 Mayıs 2020 tarihinde https://www.youtube.com/watch?v=AzJwnvLBtbo adresinden erişildi.

Kamu Spotu "ALO 156 Jandarma İmdat Hattı". 05 Mayıs 2020 tarihinde https://www.youtube.com/watch?v=ajiHxBCgqCI adresinden erişildi.

Kamu Spotu "ALO 183 Sosyal Destek Hattı". 05 Mayis 2020 tarihinde https://www.youtube.com/watch?v=kfmTh0Skr1s adresinden erişildi.

Kamu Spotu “BALON: Kadına Şiddete HAYIR!". 05 Mayıs 2020 tarihinde https://www.youtube.com/watch?v=MZddG-CApXIEt=77s adresinden erişildi.

Kamu spotu "Biz Varı". 05 Mayıs 2020 tarihinde https://www.youtube.com/watch?v=5ME-H-7O1C4 adresinden erişildi.

Kamu spotu "Cins var Cins var". 05 May1s 2020 tarihinde https://www.youtube.com/watch?v=pmYqzXG8_dI adresinden erişildi.

Kamu spotu "Erkeksen Öfkeni Yen". 05 Mayıs 2020 tarihinde https://www.youtube.com/watch?v=rPUn5BKFDDw adresinden erişildi.

Kamu spotu "Evdeki Şiddet Hapiste Biter". 05 Mayıs 2020 tarihinde https://www.youtube.com/watch?v=x7LJKMk21OE adresinden erişildi.

Kamu spotu "Güvenli Bir Hayat Var". 05 Mayıs 2020 tarihinde https://www.youtube.com/watch?v=RvHBW0JWm8U adresinden erişildi.

Kamu Spotu "Kadın Destek Uygulaması". 05 Mayıs 2020 tarihinde https://www.youtube.com/watch?v=8gSBvFLD8RY adresinden erişildi.

Kamu Spotu "Kadın Hayattır!". 05 Mayıs 2020 tarihinde https://www.youtube.com/watch?v=tOvBDAI2z1Q adresinden erişildi.

Kamu Spotu "Kadın Hayattır!". 05 Mayı 2020 tarihinde https://www.youtube.com/watch?v=tOvBDAI2z1Q adresinden erişildi.

Kamu Spotu "Kadına El Kaldıran Bizi Karşısında Bulur". 05 Mayıs 2020 tarihinde https://www.youtube.com/watch?v=eAoL6WMDI9I adresinden erişildi. 
Kamu Spotu “Kadına Şiddet İnsanlığa İhanettir!” 1. Bölüm. 05 Mayıs 2020 tarihinde https://www.youtube.com/watch?v=ZBW5KBmxqYk adresinden erişildi.

Kamu Spotu "Kadına Şiddet İnsanlığa İhanettir!" 2. Bölüm. 05 Mayıs 2020 tarihinde https://www.youtube.com/watch?v=UQrn5aTVyMI adresinden erişildi.

Kamu Spotu "Kadına Şiddet Suçtur. Ortak Olma, Seyirci Kalma". 05 Mayıs 2020 tarihinde https://www.youtube.com/watch?v=DDstn65eczA adresinden erişildi.

Kamu Spotu "Kadına Şiddete Hayır!". 05 Mayıs 2020 tarihinde https://www.youtube.com/watch?v=cGzCkJ78mno adresinden erişildi.

Kamu Spotu “Kadına Şiddete Karşı Buradayım De". 05 Mayıs 2020 tarihinde https://www.youtube.com/watch?v=ycYYgYboat $A$ adresinden erişildi.

Kamu Spotu "Kadına Şiddete Karşı Sıfır Tolerans". 05 Mayıs 2020 tarihinde https://www.youtube.com/watch?v=s7poT9pi74c adresinden erişildi.

Kamu Spotu "Kadına Yönelik Şiddete Birlikte Dur Diyelim". 05 Mayıs 2020 tarihinde https://www.youtube.com/watch?v=S0Qe0J59WIA adresinden erişildi.

Kamu Spotu "Kimse Zorla Evlendirilemez". 05 Mayıs 2020 tarihinde https://www.youtube.com/watch?v=E4T1t0TWMqQ adresinden erişildi.

Kamu Spotu “Korkma Unutma" (“\#Şiddeti Sen Durdurabilirsin"). 05 Mayıs 2020 tarihinde $h t t p s: / / w w w . y o u t u b e . c o m / w a t c h ? v=I U a G E J 1 e 0 A M$ adresinden erişildi.

Kamu Spotu “Önce Adam Ol!". 05 Mayıs 2020 tarihinde https://www.youtube.com/watch?v=5WIiaump YEA adresinden erişildi.

Kamu Spotu "Sen Varsan, Şiddete Yer Yok". 05 Mayıs 2020 tarihinde https://www.youtube.com/watch?v=WU1_A_7OuGY adresinden erişildi.

Kamu Spotu "Sevdiklerine “Hangi Yüzle" Bakıyorsun?". 05 Mayıs 2020 tarihinde https://www.youtube.com/watch?v=GwYJcJl7hxI adresinden erişildi.

Kamu Spotu “Sevginin Yerini Şiddet Almasın" (“\#8mart8kadın”). 05 Mayıs

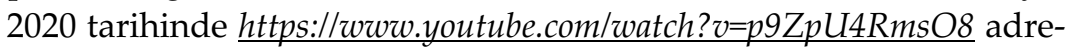
sinden erişildi.

Kamu Spotu “Şiddete Dur De!”. 05 Mayıs 2020 tarihinde https://www youtube.com/watch?v=C2snCTqKMfw adresinden erişildi. 
Kamu Spotu "Şiddetin Bahanesi Yoktur". 05 Mayıs 2020 tarihinde https://www.youtube.com/watch?v=cKiTX2ldXLU adresinden erişildi.

Kamu Spotu "Yarım Kalma". 05 Mayı 2020 tarihinde https://www.youtube.com/watch?v=ywOt9nFy4I0 adresinden erişildi.

Karaca, S., Ünsal Barlas, G., Öngün, E., Can Öz, Y., ve Korkmaz, G. (2017). Gazetelerde bulunan kadına yönelik şiddet haberlerinin incelenmesi, JAREN/Hemşirelik Akademik Araştırma Dergisi, 3(3), 137-144.

Kareklas, I., Muehling, D. D., ve Weber, T. J. (2015). Reexamining health messages in the digital age: A fresh look at source credibility effects. Journal of Advertising, 44(2), 88-104.

Kotler Philip, A. G., ve Gary, A. (1999). Principles of marketing. Europe: Prentice Hall.

Kotler, P., Shalowitz, J. I., ve Stevens, R. J. (2008). Strategic marketing for health care organizations: building a customer-driven health system. John Wiley and Sons.

Krug, E. G., Mercy, J. A., Dahlberg, L. L., ve Zwi, A. B. (2002). The world report on violence and health, The Lancet, 360(9339), 1083-1088.

McMahon, S., ve Banyard, V. L. (2012). When can I help? A conceptual framework for the prevention of sexual violence through bystander intervention, Trauma, Violence and Abuse, 13(1), 3-14.

Nakip, M., ve Yaraş, E. (2016). SPSS uygulamalı pazarlama araştırmalarına giriş. Ankara, Seçkin Yayıncılık.

Nevala, S. (2014). Violence against women: An EU-wide survey, European Union agency for fundamental rights.

Özbük, M. Y., ve Öz, Y. (2017). Türkiye'de yayınlanmış olan kamu spotlar1nın içerik analizi yöntemi ile incelenmesi. Business and Economics Research Journal, 8(3), 575-590.

Öztürk, M. C. (2015). Sosyal medya ve kurumsal iletişim. Dijital İletişim ve Yeni Medya içinde (Ed, MC Öztürk). Eskişehir: Anadolu Üniversitesi Yayınlar1, 120-152.

Page, A. Z., ve İnce, M. (2008). Aile içi şiddet konusunda bir derleme. Türk Psikoloji Yazıları, 11(22), 81-94.

Petty, R. E., ve Cacioppo, J. T. (1984). The effects of involvement on responses to argument quantity and quality: Central and peripheral routes to persuasion. Journal of personality and social psychology, 46(1), 69. 
Shaver, P., Schwartz, J., Kirson, D., ve O'connor, C. (1987). Emotion knowledge: further exploration of a prototype approach. Journal of personality and social psychology, 52(6), 1061.

Sosyal Reklam "İçimizden Birileri" 1. Bölüm. 05 Mayıs 2020 tarihinde https://www.youtube.com/watch?v=0CabNnPcmj0 adresinden erişildi.

Sosyal Reklam "İçimizden Birileri" 2. Bölüm. 05 Mayıs 2020 tarihinde https://www.youtube.com/watch?v=Gt4LaZQh4R4 adresinden erişildi.

Sosyal Reklam "İçimizden Birileri" 3. Bölüm. 05 Mayıs 2020 tarihinde https://www.youtube.com/watch?v=zegSwUWeEzc adresinden erişildi.

Sosyal Reklam "İçimizden Birileri" 5. Bölüm. 05 Mayıs 2020 tarihinde https://www.youtube.com/watch?v=9c9ML8Qjz-4 adresinden erişildi.

Sosyal Reklam "İçimizden Birileri" 6. Bölüm. 05 Mayıs 2020 tarihinde https://www.youtube.com/watch?v=NQKDcOgP688 adresinden erişildi.

Sosyal Reklam "Suç Bende Değil" 2. Bölüm. 05 Mayıs 2020 tarihinde https://www.youtube.com/watch?v=QFxkR1JiddM;

https://www.youtube.com/watch?v=n 4QJLwRDis adreslerinden erişildi.

Sosyal Reklam "Suç Bende Değil" 3. Bölüm. 05 Mayıs 2020 tarihinde https://www.youtube.com/watch?v=wraxj9OzA78\& $t=731 \mathrm{~s}$ adresinden erişildi.

Sosyal Reklam "Suç Bende Değil" 4. Bölüm. 05 Mayıs 2020 tarihinde https://www.youtube.com/watch?v=Cbr9IbHuNOQ adresinden erişildi.

Sosyal Reklam "Suç Bende Değil" 5. Bölüm. 05 Mayıs 2020 tarihinde https://www.youtube.com/watch?v=lLQZ-OeISGQE $t=1221$ s adresinden erişildi.

Sosyal Reklam "Suç Bende Değil" 6. Bölüm. 05 Mayıs 2020 tarihinde https://www.youtube.com/watch?v=foK3KBqRKW0Et=357s;

https://www.youtube.com/watch?v=2Vg27RESGVI adreslerinden erişildi.

Stemler, S. (2000). An overview of content analysis. Practical assessment, research, and evaluation, 7(1), 17.

Suç Bende Değil 1. Bölüm. 05 Mayıs 2020 tarihinde https://www.youtube.com/watch?v=wL1tlrAEYSw\&t=2s;

https://www.youtube.com/watch?v=NetXf-7H77s\&t=441s adreslerinden erişildi.

Şeker, M., ve Tiryaki, S. (2013). Sigara ile ilgili kamu spotlarında moral panik etkisi. Selçuk Üniversitesi Türkiyat Araştırmaları Dergisi, 33, 223-241. 
Tanca, H. A., ve Ünal, F. (2018). Student views about the public spot advertisement signs in the context of lifelong learning (The example of reading culture themed public spot advertisement). Journal of Education and Learning, 7(2), 101-110.

Tozlu, C., ve Göksel, A. (2016). WAVE: Violence against women country report Turkey.

Türkoğlu, S. (2014). Kadına yönelik şiddeti özendiren diziler üzerine etki araştırması. Atatürk Iletişim Dergisi, 7, 143-160.

Tversky, A., ve Kahneman, D. (1991). Loss aversion in riskless choice: A reference-dependent model. The quarterly journal of economics, 106(4), 1039-1061.

Umunç, C. (2019). Kadına yönelik şiddet temalı kamu spotlarının göstergebilimsel çözümlemesi. Afyon Kocatepe Üniversitesi Sosyal Bilimler Dergisi, 21(4), 1316-1334.

Uslusoy, B. S. (2016). Neoliberalizm ve tüketim toplumu bağlamında yapısal şiddetin reklamlarda yeniden inşası. Journal of International Social Research, 9(43),2134-2143.

Vodinalı, S. ve Akıncı Ç. N. (2019) "Kadına Yönelik Şiddete Hayır" teması bağlamında biz varız adlı kamu spotu üzerine bir değerlendirme. Abant Kültürel Araştırmalar Dergisi, 4(7), 36-50.

Wettersten, K. B., Rudolph, S. E., Faul, K., Gallagher, K., Trangsrud, H. B., Adams, K., Graham, S., ve Terrance, C. (2004). Freedom through self-sufficiency: A qualitative examination of the impact of domestic violence on the working lives of women in shelter. Journal of Counseling Psychology, 51(4), 447-462. doi: https://doi.org/10.1037/00220167.51.4.447.

World Health Organization (2019). RESPECT women: Preventing violence against women. Geneva (WHO/RHR/18.19). Licence: CC BY-MC-SA 3.0 IGO.

World Health Organization. (2013). Global and regional estimates of violence against women: prevalence and health effects of intimate partner violence and non-partner sexual violence. World Health Organization.

Yaman, F., ve Göçkan, İ. (2015). Kamu spotu reklamlarının sigara kullanıc1ları üzerindeki etkisi: Afyonkarahisar ilinde bir uygulama. Kafkas University. Faculty of Economics and Administrative Sciences. Journal, 6(11), 53-65. 
Youtube Aile İçi Şiddete Son Resmi Kanalı. 05 Mayıs 2020 tarihinde https://www.youtube.com/user/aileicisiddeteson/videos adresinden erişildi.

Youtube Aile ve Sosyal Politikalar Bakanlığı Resmi Dijital Kütüphane Kanal. $05 \quad$ Mayis 2020 tarihinde https://www.youtube.com/channel/UChZBC0A260gwDqjljuALKg/search?query $=\%$ C5\%9Fiddet adresinden erişildi.

Zalluhoğlu, A. E., Karslı, C., Candemir, A., ve Günay, N. (2015). Sosyal pazarlama çerçevesinde kamu spotlarının incelenmesi: Keşifsel bir analiz. 2. U. Kongresi (DÜ), Eskişehir.

\section{Kaynakça Bilgisi / Citation Information}

Yetişer, B. (2021). Türkiye' de kadına şiddet konusunu içeren medya yayınlarının içerik analizi ile incelenmesi . OPUS-Uluslararası Toplum Araştırmaları Dergisi, 18(39), 60-97. DOI: 10.26466/opus. 814844 